\title{
ポリカルボン酸系高性能 AE 減水剂の気泡について ON ENTRAINING AIR OF POLYCARBOXYLATE TYPE WATER REDUCER
}

\author{
枚田 健*, 名和 豊 春**
}

Tsuyoshi HIRATA and Toyoharu NAWA

\begin{abstract}
From the results obtained in this study, it is concluded that the quantity of bubbles that PC- $n$, which is polycarboxylate having poly $(n)$ ethylene glycol groups as side chains, introduces in concrete can be reduced when the side chains' length ' $n$ ' is designed to be longer than $25 \mathrm{~mol}$. But basically it is suggested that PC- $n$ would have the air entraining performance in itself, By using the specific $\mathrm{AE}$ agent and anti-foaming agent, the stable bubbles can replace the unstable ones PC-10 introduced in concrete. As a result the excellently durable concrete can be manufactured that maintains the relative dynamic Young's modulus beyond $90 \%$ till about 1,200 cycles.
\end{abstract}

Keywords: polycarboxylate type water reducer, air entraining performance, freezing and thawing ポリカルボン酸系高性能 $\mathrm{AE}$ 減水剂, 空気連行性, 凍結融解抵抗性

\section{1.はじめに}

ポリカルボン酸（PC と略す）を主原料とする PC 系高性能 $\mathrm{AE}$ 減 水剤は減水性能とスランプ保持性能に優れ, 各種の高性能なコンク リートに広く応用されている1)，2)。

PC の代表的な例としては, Scheme 1 に示した構造のポリマーが 挙げられる。すなわち, 酸化エチレン（EO）の平均付加モル数が $n$ モルのメトキシポリエチレングリコール (PGM- $n$ と略す) とメタク リル酸（MAA）とのエステル化反応物であるメトキシポリエチレン グリコールモノメタクリレート（PGM- $n \mathrm{E}$ と略す）と MAA または メタクリル酸ナトリウム（SMAA と略す）とのコポリマー（PC-n と略す) である。

一方で $\mathrm{PC}$ 系高性能 $\mathrm{AE}$ 減水剤には, 空気を連行しやすく, 適切 な空気量の管理が難しいという問題がある ${ }^{3)}$ 。著者らは, 前報 ${ }^{4)}$ でこのPCのポリマー構造と空気連行性（AE 性）に関する検討を行 い, 次のことを明らかにした。

(1) 側鎖の長さが 10 モルの PC-10 水溶液は, 晴り点を利用してポ リマーを精製でき, 空気連行性物質（AE 性物質）を除去する

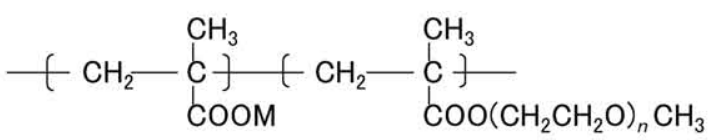

(M: - H または - $\mathrm{Na})$

MAA PGM- $n \mathrm{E}$

Scheme 1. PC-n $n$ 構造式
ことができる。その結果, $\mathrm{AE}$ 性が低減される。

(2) $\mathrm{PC}-10$ の $\mathrm{AE}$ 性物質は, 低分子量のポリマーと未反応で残存し ている側鎖原料の PGM-10 であり，特に PGM-10 は強い AE 性 を示す。

(3) セメントペースト中で, PC-10 は，側鎖と主鎖をつないでいる エステル結合が，加水分解を受けて PGM-10 を脱離する。

(4) セメントペースト中で側鎖が脱離しても AE 性を与えない側鎖 の構造としては, 末端基が-Hであるか, あるいは, 末端基が- $\mathrm{CH}_{3}$ の場合には $n$ はおよそ 30 以上の長さが必要である。

そこで, 本研究では, 側鎖長 $n$ を $25,30,35$ と伸ばしたPC-25, PC-30, PC-35を合成し，それらのAE性をPC-10と比較した。

また, PCは一般のポリマーと同様に, 共重合反応した後のポリマ 一組成は仕込んだモノマーの組成比どおりにはならずに分布があり, 分子量分布も広い。したがって, PCは組成比が少しずつ異なるポリ マー分子で構成されることになり, 個々のポリマー分子は界面活性 が異なるであろう。界面活性は気泡の安定性と関連しており，PCを 構成するポリマーの内には気泡を安定にするものもあれば不安定に するものもあると考えられる。そこで, PCが連行する気泡はすべて 消泡剂で消して, 単一の分子からなる界面活性剤を用い安定で微細 な気泡を導入することができれば, 耐凍害性が向上する可能性があ ると推測した。以上のことを検証するため, PCで作製したコンクリ 一トと, これと同じ空気量になるようにPCに消泡剤と界面活性剤 (AE凨) を加えたコンクリートを作製し，それらの凍結融解抵抗性，
* (株)日本触媒 上席研究員 - 工修 北海道大学大学院工学研究科環境循環システム専攻 博士後期課程

***北海道大学大学院工学研究科環境循環システム専攻 教授. 工博
Nippon Shokubai Fellow, Nippon Shokubai Co., Ltd, M. Eng.

Graduate Student, Graduate School of Eng., Hokkaido University

Prof., Division of Solid Waste, Resources and Geoenvironmental Engineering, Hokkaido University, Dr. Eng. 
気泡組織, 圧縮強度, 凝結時間を比較した。

\section{2. 用いた PC の合成とキャラクタリゼーション及び表面張カの測} 定

\section{2. $1 P C$ の合成}

PC-10 は, モノマー組成比（PGM-10E/SMAA） 75/25, 重合温度 $50 \pm 2^{\circ} \mathrm{C}$, 重合浱度 20 質量 $\%$, MAA 中和率 $10 \%$, 重合触媒に過硫酸 アンモニウムと亜硫酸水素ナトリウムのレドックス系を用いて水溶 液中で重合して得た。得られたポリマーの重量平均分子量 $(M w)$ は 後述の GPC を用いた方法で測定し, 35000 という值を得た。なお, モノマー組成比は, 重合反応に用いた PGM-10E の質量と, 用いた MAA と SMAA の質量をすべて SMAA に換算したときの質量比率 (PGM- $n$ E/SMAA) である。得られた PC-10 は，是り点による精製 を行い4)， $\mathrm{AE}$ 性物質を除去して用いた。

PC-25, PC-30, PC-35 は, モノマー組成比 (PGM- $n$ E/SMAA) 80/20, 重合温度 $80 \pm 2^{\circ} \mathrm{C}$, 重合濃度 45 質量\%, MAA 未中和の条件にて水溶 液中で重合して得た。重合触媒には過硫酸アンモニウムを用い, 連 鎖移動剂にメルカプトプロピオン酸を用いた。得られたポリマーに は曇り点による精製は行わなかった。

得られた PC-10，PC-25，PC-30，PC-35 は，水酸化ナトリウムで 中和し, Scheme 1 に示寸MAA 単位をSMAA 単位に変換して用いた。 Table 1 に, 用いたPCのモノマー組成比を質量比とモル比で示す。

なお，著者らは既報 5) で，PC-10，PC-23，PC-90 についてモル タルフロー値を最大にするモノマー組成比 (PGM- $n \mathrm{E} / \mathrm{SMAA}$, 質量 比）が，それぞれ 70/30〜80/20，80/20，90/10 であることを報告し ている。そこで, 本研究ではモノマー組成比として PC-10 は 75/25; PC-25，PC-30，PC-35 は80/20を用いた。

Table 1. モノマー組成比
\begin{tabular}{|c|c|c|c|}
\hline \multirow{2}{*}{$n$} & \multirow{2}{*}{$n$} & \multicolumn{2}{|c|}{$\mathrm{PGM} \cdot n \mathrm{E} / \mathrm{SMAA}$} \\
\cline { 3 - 4 } & & (質量比) & (モル比) \\
\hline $\mathrm{PC} \cdot 10$ & 10 & $75 / 25$ & $1.0 / 1.7$ \\
\hline $\mathrm{PC}-25$ & 25 & $80 / 20$ & $1.0 / 2.8$ \\
\hline $\mathrm{PC}-30$ & 30 & $80 / 20$ & $1.0 / 3.3$ \\
\hline $\mathrm{PC}-35$ & 35 & $80 / 20$ & $1.0 / 3.8$ \\
\hline
\end{tabular}

\section{2. $2 \mathrm{PC}$ のキャラクタリゼーション: ゲル浸透クロマトグラフィ}

\section{- (GPC) による重量平均分子量 $(M w)$ の測定}

充填材にシリカゲル系を用い, カラム温度は $40^{\circ} \mathrm{C}$ とした。溶離液 にはアセトニトリル $6001 \mathrm{~g}$, 水 $10999 \mathrm{~g}$, 酢酸ナトリウム三水和物 $115.6 \mathrm{~g}$ を混合して酢酸で $\mathrm{pH} 6.0$ に調整したものを用いた。溶離液の 流速は $1.0 \mathrm{~mL} / \mathrm{min}$.として, サンプル濃度は溶離液で $0.5 \%$ となるよう に希釈し, サンプル注入量は $100 \mu \mathrm{L}$, 検出器に UV 検出器（波長 $220 \mathrm{~nm}$ ）を用いて測定を行った。なお，サンプルは $0.45 \mu \mathrm{m}$ のフィル ターでろ過し, 検量線作成標準物質にはポリエチレングリコールを 用いた。

\section{3 表面張力の測定}

PC-10 を添加したコンクリート (コンクリート A と略す) と, PC-10 によって連行された気泡を消すための消泡郕とコンクリート A と 同じ空気量に復帰させるために $\mathrm{AE}$ 鼡を $\mathrm{PC}-10$ とともに添加したコ ンクリート (コンクリート C と略寸) で, それらの気泡の安定性を, 各種の溶液の表面張力から検討した。

表面張力の測定は，まず，コンクリート A およびコンクリート C と同じ水セメント比のセメントペーストを調製し，これをろ過して セメントペースト中の溶液（以下, セメントろ液と称す）を得, こ のセメントろ液に PC-10, あるいは PC-10 と消泡剤および AE 剂を 加えて行った。また，比較のためにセメントろ液を水に代えて同様 に PC-10, あるいは PC-10 と消泡剂および $\mathrm{AE}$ 剂を加えた水溶液 $\mathrm{A}$ と水溶液 C を調製しそれらの表面張力も測定した。

表面張力の測定には, 動的表面張力計 (SITA science line t60 ; SITA Messtechnik GmbH 社, ドイッ) を用いた。動的表面張力 $\sigma$ は, 溶液 に挿入した半径 $\mathrm{r}$ のキャピラリーから空気を圧入して気泡を発生さ せ, この時の圧力 $\Delta \mathrm{p}$ を測定して Young-Laplace の式（下式(1)）か ら求められた。測定温度は $21.5 \pm 0.5^{\circ} \mathrm{C}$ で行った。そして, 水の表面 張力が $72.5 \mathrm{mN} / \mathrm{m}$ の時の気泡発生数はおよそ 0.5 個/秒に相当し, こ の時の測定值を静的表面張力の近似值として用いた。

$$
\sigma=\Delta p \cdot r / 2
$$

\section{3. モルタルおよびコンクリートの性能試験 \\ 3. 1 モルタル試験}

モルタル試験ではPC-25, PC-30, PC-35のAE性を, PC-10と比較し た。砂は豊浦産標準砂を用い, Table 2 に示すモルタル調合とした。 なお，モルタルへのPC添加量はセメント質量に対する固形分換算質 量百分率（\%）で表記することとした。また，セメントは普通ポル トランドセメント（以下，セメントと略す）を用いた。

モルタルは室温下でセメント, 豊浦産標準砂, そしてPC-10, PC-25, PC-30, PC-35を添加した水をモルタルミキサーで3分間混練して作製 し, 混練直後のフロー值, 空気量を測定した。フロー值は, 水平な ステンレス板上に置いた内径 $50 \mathrm{~mm}$, 高さ $50 \mathrm{~mm}$ の塩化ビニル製中空 円筒にモルタルをすり切りまで充填し, 中空円筒を静かに持ち上げ た後に広がったモルタルの直交する長径と短径の平均值から求めた。 空気量は，モルタル全量を容量 $600 \mathrm{~mL}$ モプラスチック容器に隙間な く充填し, その容積と質量, 材料の密度から算出した。

\begin{tabular}{|c|c|c|c|c|}
\hline $\begin{array}{l}\text { PC-10 } \\
(\%)^{\text {b) }}\end{array}$ & $\begin{array}{l}\mathrm{W} / \mathrm{C} \\
(\%)\end{array}$ & $\begin{array}{l}W \\
(\mathrm{~g})\end{array}$ & $\begin{array}{c}\mathrm{C} \\
(\mathrm{g})\end{array}$ & $\begin{array}{l}S^{\text {a) }} \\
\text { (g) }\end{array}$ \\
\hline 0.15 & $60 \%$ & 240 & 400 & 800 \\
\hline
\end{tabular}

Table 3. コンクリート調合

\begin{tabular}{|c|c|c|c|c|c|c|c|c|c|c|}
\hline \multirow[b]{2}{*}{ No. } & \multicolumn{3}{|c|}{ 添加㓣 } & \multirow[b]{2}{*}{ 骨材の品質 } & \multirow{2}{*}{$\begin{array}{c}\text { W/C } \\
(\%)\end{array}$} & \multirow{2}{*}{$\begin{array}{l}\text { s/a } \\
(\%)\end{array}$} & \multicolumn{4}{|c|}{ 単位量 $\left(\mathrm{kg} / \mathrm{m}^{3}\right)$} \\
\hline & $\begin{array}{l}\mathrm{PC} \cdot n \\
(\%)^{\text {a) }}\end{array}$ & $\underset{\text { b) }}{\operatorname{POA}(\%)}$ & $\begin{array}{c}\text { POES } \\
(\%)^{b)}\end{array}$ & & & & W & $\mathrm{C}$ & $\mathrm{S}$ & G \\
\hline \multirow{2}{*}{ MIX 1} & $\mathrm{PC} \cdot 10,0.24$ & $0 \sim 1.5$ & $0 \sim 0.6$ & Table 4, No. (1) & \multirow{2}{*}{47.0} & \multirow{2}{*}{50.0} & \multirow{2}{*}{165} & \multirow{2}{*}{350} & \multirow{2}{*}{857} & \multirow{2}{*}{901} \\
\hline & $\mathrm{PC} \cdot 10,0.11$ & $0,0.5$ & $0,0.25$ & Table 4 , No. (2) & & & & & & \\
\hline MIX 2 & $\mathrm{PC} \cdot 10,0.15$ & $0,0.5$ & $0,0.25$ & Table 4, No. (3) & 48.1 & 46.0 & 169 & 350 & 794 & 973 \\
\hline MIX 3 & $\mathrm{PC} \cdot 25,0.17$ & 0 & 0 & Table 4, No. (4) & 51.3 & 48.0 & 164 & 320 & 846 & 951 \\
\hline
\end{tabular}

a) セメント質量に対する質量\%, b) PC-10質量に対寸る質量\%, 


\section{2 コンクリート試験}

（1）コンクリートの作製

コンクリートはコンクリートAとコンクリートC, およびコンクリ

ートCよりも消泡剤と $\mathrm{AE}$ 凰の量を増やして作製したコンクリートD の3種類を用いた。そして, コンクリートの凍結融解抵抗性, 気泡組 織, 圧縮強度, 凝結時間を比較した。また, 気泡組織の測定は, 練 り上がり直後のフレッシュコンクリートと, 練り上がり直後のコン クリートを採取した硬化コンクリート（気中養生1日後，水中鿾生2 日：材令 3 日と略す）の 2 水準で行った。消泡剤にはポリオキシアル キレンアルキルエーテル（POA），AE郕にはポリオキシエチレンア ルキルエーテル硫酸ナトリウム (POES) を用いた。なお，コンクリ ートへのPC添加量はセメント質量に対する固形分換算質量百分率 （\%）で表記することとした。

コンクリートは, 温度 $20 \pm 2^{\circ} \mathrm{C}$, 湿度 $60 \pm 5 \%$ の恒温恒湿室で, 温度 $20^{\circ} \mathrm{C}$ に調整した材料（骨材は表乾状態）を用い，容量 $100 \mathrm{~L} の$ 強制練 りミキサで練り混ぜた。コンクリートの調合をTable 3, 用いた骨材 の品質をTable 4に示す。

コンクリートは, セメント, 細骨材, 粗骨材を 10 秒間空練りした 後, PC-10, あるいはPC-10とPOA, POESを含んだ水を加えて90秒間 混練して作製し，排出した直後にスランプと空気量を測定した。そ の後, 練り板上で乾かないようにシートで覆って静置し, 所定時間 ごとに練り返して, スランプと空気量の経時変化を調べた。スラン プ, 空気量, 圧縮強度, 凝結時間は, それぞれJIS A 1101, JIS A 1128, JIS A 1108, JIS A 6204の方法に準じて測定した。そして, フレッシ ユコンクリートと硬化コンクリートの気泡組織の測定, 及び硬化コ ンクリートの凍結融解試験は, 下記に示寸方法 (2) 〜 (4) で行っ た。また，それぞれの測定で用いたコンクリート調合と骨材の種類 をTable 5 にまとめる。

Table 4. 骨材の品質

\begin{tabular}{|c|c|c|c|c|c|c|c|c|}
\hline No. & 骨材 & 種類 & $\begin{array}{c}\text { 最大寸法 } \\
(\mathrm{mm})\end{array}$ & $\begin{array}{l}\text { 絶乾比重 } \\
\left(\mathrm{g} / \mathrm{cm}^{3}\right)\end{array}$ & $\begin{array}{c}\text { 吸水率 } \\
(\%) \\
\end{array}$ & $\begin{array}{c}\text { 単位容積質量 } \\
\left(\mathrm{g} / \mathrm{cm}^{3}\right)\end{array}$ & $\begin{array}{c}\text { 実積率 } \\
(\%) \\
(\%)\end{array}$ & $\begin{array}{c}\text { 粗粒率 } \\
(\%) \\
\end{array}$ \\
\hline \multirow{2}{*}{ (1) } & 粗骨材 & 青梅産砕石 & 20 & 2.69 & 0.63 & 1.63 & 60.4 & 6.54 \\
\hline & 細骨材 & 掛川産川砂 & 5 & 2.55 & 1.74 & 1.73 & 67.8 & 2.42 \\
\hline \multirow{2}{*}{ (2) } & 粗骨材 & 青梅産砕石 & 20 & 2.63 & 0.69 & 1.63 & 62.0 & 6.67 \\
\hline & 細骨材 & 君津産山砂 & 5 & 2.61 & 1.14 & 1.78 & 68.2 & 2.53 \\
\hline \multirow{2}{*}{ (3) } & 粗骨材 & 青梅産砕石 & 20 & 2.63 & 0.69 & 1.63 & 62.0 & 6.67 \\
\hline & 細骨材 & 掛川産川砂 & 5 & 2.53 & 2.01 & 1.70 & 67.0 & 2.39 \\
\hline \multirow{3}{*}{ (4) } & 粗骨材 & 青梅産砕石 & 20 & 2.70 & 0.69 & 1.63 & 60.4 & 6.54 \\
\hline & \multirow{2}{*}{ 細骨材 a) } & 掛川産川砂 & 5 & 2.55 & 1.60 & 1.76 & 69.0 & 2.61 \\
\hline & & 君津産山砂 & 5 & 2.63 & 0.90 & 1.79 & 67.9 & 2.42 \\
\hline
\end{tabular}

a) 掛川産川砂と君津産山砂を6:4の割合で混合して用いた。

Table 5. コンクリート試験の項目と調合

\begin{tabular}{|c|c|c|c|c|c|c|}
\hline \multirow{2}{*}{ No. } & \multirow{2}{*}{ コンクリートの種類 } & \multirow{2}{*}{ 試験項目 } & \multirow{2}{*}{$\begin{array}{l}\text { コンクリート調合 } \\
\text { (Table 3, No.) }\end{array}$} & \multicolumn{3}{|c|}{ 骨材の種類 } \\
\hline & & & & 粗骨材 & 細骨材 & Table 4 \\
\hline 1 & \multirow{6}{*}{ フレッシュコンクリート } & \multirow{4}{*}{ スランブ, 空気量 } & MIX 1 & \multirow{11}{*}{ 青梅産砕石 } & 掛川産川砂 & No. (1) \\
\hline 2 & & & MIX 1 & & 君津産山砂 & No. (2) \\
\hline 3 & & & MIX 2 & & 掛川産川砂 & No. (3) \\
\hline 4 & & & MIX 3 & & 掛川産川砂 & No. (4) \\
\hline 5 & & \multirow{2}{*}{ 気泡分布 } & MIX 2 & & 掛川産川砂 & No. (3) \\
\hline 6 & & & MIX 3 & & 掛川産川砂 & No. (4) \\
\hline 7 & \multirow{5}{*}{ 硬化コンクリート } & 凍結融解 & MIX 1 & & 掛川産川砂 & No. (1) \\
\hline 8 & & \multirow{2}{*}{ 気泡分布 } & MIX 1 & & 掛川産川砂 & No. (1) \\
\hline 9 & & & MIX 2 & & 掛川産川砂 & No. (3) \\
\hline 10 & & 圧縮強度 & MIX 1 & & 君津産山砂 & No. (2) \\
\hline 11 & & 凝結時間 & MIX 1 & & 君津産山砂 & No. (2) \\
\hline
\end{tabular}

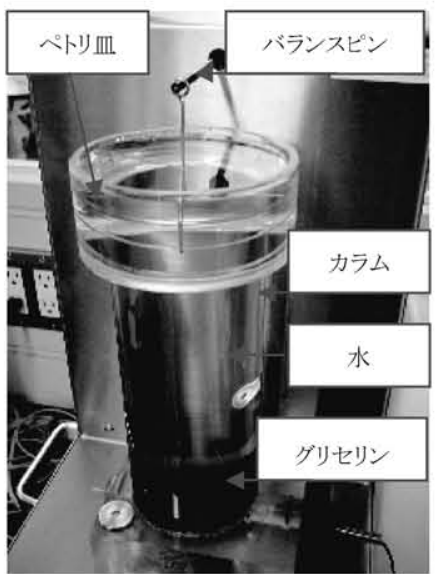

Photo. 1 AVAの外観

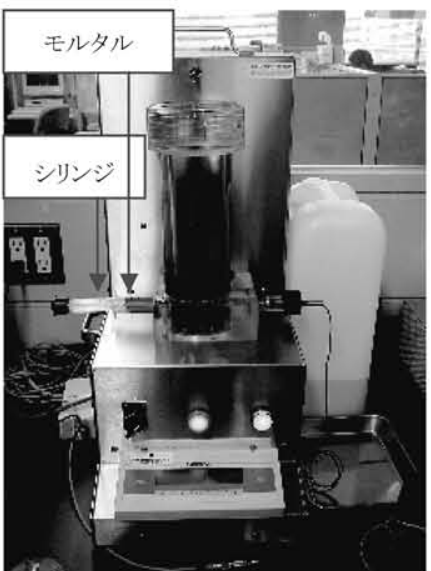

Photo. 2 AVA の外観

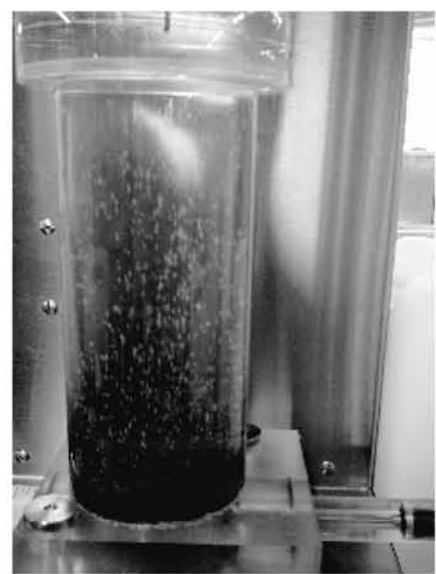

Photo. 3 測定中のようす 


\section{（2）フレッシュコンクリートの気泡組織の測定}

フレッシュコンクリートの気泡組織の分析は, GERMANN INSTRUMENTS 製の AIR VOID ANALYZER（AVA と略す）を用 いて行った ${ }^{6)}$ 。AVA の測定原理は, 気泡の浮力の変化を測定しス トークスの法則を用いて気泡組織を解析する方法（浮力法）に基づ く7)。AVAの外観と測定中のようすを Photo. 1 Photo. 3 に示す。

Photo. 1 : カラム内に擋拌子を入れ, 水を満たした後, グリセリン を入れる。グリセリンは比重が 1 より大きい $\left(1.261 \mathrm{~g} / \mathrm{cm}^{3}\right)$ ので下 に沈む。そして, 上部のバランスピンにペトリ血を撕ける。この時, ペトリ皿がカラムに触れないように注意する。

Photo. 2 : シリンジにモルタルを $20 \mathrm{~cm}^{3}$ 採取し, グリセリンで満た されたカラム底部に装着する。グリセリンが擋汼子で摚拌されてお り, カラム温度が $23 \pm 2{ }^{\circ} \mathrm{C}$ で, AVA プログラムが測定待機状態であ ることを確認後, シリンジ内のモルタルをグリセリン中に押し出し て測定を開始する。

Photo. 3 : モルタルに含まれる気泡はグリセリンから上層の水層へ とストークスの原理にしたがって大きな気泡から順に抜ける。そし て,それらの気泡を水層上部に設置したペトリ血で捕集して秤量し, 測定される重量変化から浮力変化を求め, それを気泡数に換算して 気泡パラメーターを測定する。

本研究では, 練り上がり直後, 30 分後, 60 分後, 90 分後のコン クリートから一部を採取して振動ケージで $6 \mathrm{~mm}$ 以上の石を取り除 き, 得られたモルタルの気泡パラメーターを測定した。

\section{（3）硬化コンクリートの気泡組織の測定}

硬化コンクリートの気泡組織の分析には, (株) ファーストー (株) 八洋コンサルタント製の硬化コンクリート気泡計測装置 HF-MAC01 を用いた。測定は, ASTM C 457 に準拠したリニアトラバース法を 自動化測定することによって行い，気泡パラメーターを計測した。

\section{（4）凍結融解試験}

凍結融解試験は, JIS A 1148 の方法に準じて測定した。 試験に用いた供試体は, 型枠を取り外すまでは温度 $20 \pm 3^{\circ} \mathrm{C}$ の室内 で乾燥しないように養生し,成形後約 24 時間で型枠を取り外した後, 温度 $20 \pm 2^{\circ} \mathrm{C}$ の水中で, 材齢が 28 日になるまで養生した後, 直ちに 凍結融解試験を開始した。供試体は 2 個採取し, 30 サイクル毎に相 対動弾性係数を測定した。

\section{4. 実験結果と考察}

\section{1 側鎖長を伸ばした PC の AE 性}

著者らは前報 ${ }^{4)}$ で, $\mathrm{PC}$ の $\mathrm{AE}$ 性を低減するには側鎖の長さ $n$ がお よそ 30 以上と長くなければならないと予測した。そこで,この予測 を確かめるために $M w$ を種々変えた PC-25, PC-30, PC-35を合成し, それらの AE 性をモルタル試験で調べた。比較のポリマーには PC-10 （Mw35000）を用い, 同じフロー値のときの空気量を比較した。添 加量はすべて $0.15 \%$ で行った。分子量とフロー值の関係を Fig. 1, 分 子量と空気量の関係を Fig. 2 に示寸。

空気量は, PC-10 が 9.7\%であるのに対して, PC-25 が 8.1〜9.2\%, PC-30 は 7.4 8.5\%，そして PC-35 は，フロー值が PC-10 とほぼ同 等であった $M w 17900$ のポリマーで $7.4 \%$ あ゙あり，側鎖が長くなるに したがって低くなった。フロー值については, 空気量に上下で $2.3 \%$ の差があったにもかかわらず，PC-10，PC-25，PC-30，PC-35

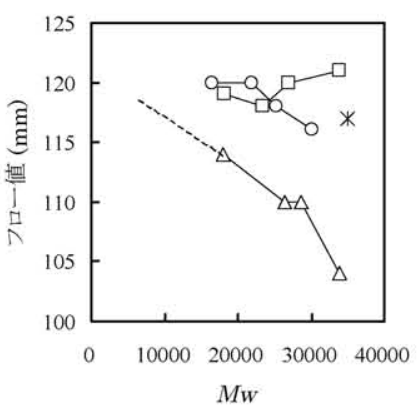

用いたPC: $\mathrm{PC}-25(\mathrm{O}), \mathrm{PC}-30(\square), \mathrm{PC}$ $35(\triangle), P C-10(*)$; モルタル調合: Table 2 ; 添加量: $0.15 \%$
Fig. 1. $\mathrm{PC} M W$ とフロー值との関倸

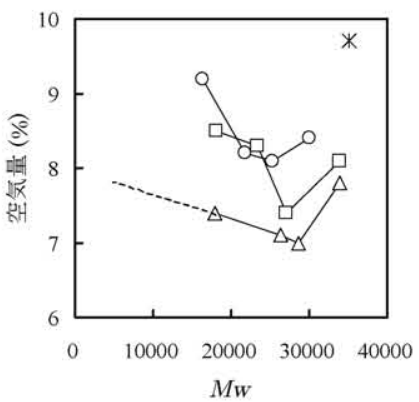

Fig. 2. $\mathrm{PC} の M W$ と空気量との関倸

用いたPC，PC-25(○)，PC-30( $\square) ， \mathrm{PC}$ $35(\mathrm{~A}), \mathrm{PC}-10(*)$; モルタル調合: Table 2 ; 添加量: $0.15 \%$.
(Mw17900) ともほぼ同等の值を示した。

PC-25, PC-30, PC-35 は，PC-10 とは違って曇り点による精製を 行わず $\mathrm{AE}$ 性物質は除去されていない。それにもかかわらず，空気 量は低かった。この結果は, PC の AE 性を低減するには側鎖の長さ $n$ がおよそ 30 以上と長くなければならないという著者らの予測を裏 付けるものであった。

また, PCはその分子構造からして, ポリエチレングリコール側鎖 とカルボキシル基を親水基とし炭化水素からなる主鎖を踈水基とす るポリマーである。このように 1 分子内に親水基と疎水基という二 つの全く相反する性質の原子団を持つことは, 界面活性剤の基本的 特性であり, 溶液中では気泡を連行しやすくする。一般に, 界面活 性剤水溶液に空気がなんらかの機械的な手段で入り込むと, 周囲を 溶液に囲まれた気泡ができる。このとき, 気泡の内部に疎水基を向 け，溶液相には親水基を向けた吸着膜が瞬間的に生成する ${ }^{8)}$ 。した がって PC は，基本的には AE 性を示すポリマーであると言える。

次に, 練り上がり直後のフレッシュコンクリートの気泡組織が PC の $M w$ でどのように変化するのかを調べた。PCには PC-25 を用い, $M w$ を $16200 ， 20000 ， 25400 ， 31400$ と変えた。

Fig. 3 および Fig. 4 に，PC-25 の添加量を $0.17 \%$ にそろえて作製し たコンクリートの練り上がり直後のスランプと空気量を示す。また, そのときの気泡分布 (積算空気量 vs. 気泡径) と, 気泡間隔係数 $v s$. $M w$ を AVA で測定した結果を Fig. 5 および Fig. 6 に示す。

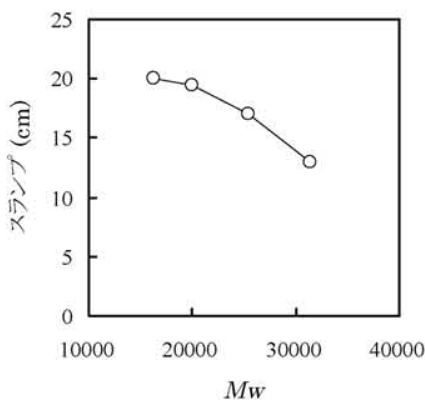

Fig. 3. PC-25の $M w$ と練り上がり直後のス ランプとの関係

コンクリート调合: Table 3, MIX 3; 骨材の品質: Table 4, No. (4); 添加量: $0.17 \%$.

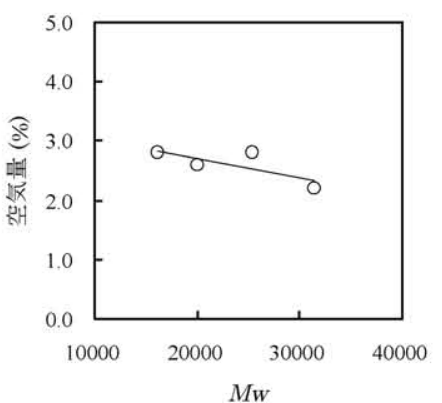

Fig. 3, Fig. 4 からわかるようにスランプと空気量は, $M w$ が下が るにつれて増える傾向にあった。そしてスランプは, $M w$ が約 1.5 


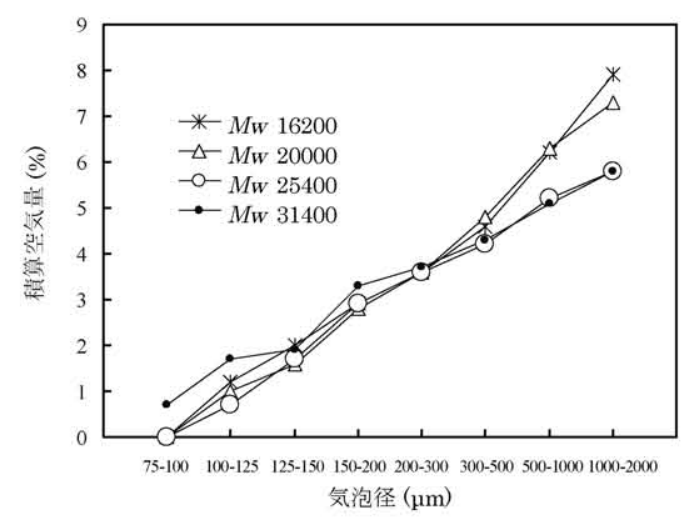

Fig. 5. 各種MWのPC-25を用いて作製された練り上がり直後のコン クリートの気泡径と積算空気量との関係

コンクリリト調合: Table 3, MIX 3; 骨材の品所: Table 4, No. (4); 添 加量: $0.17 \%$.

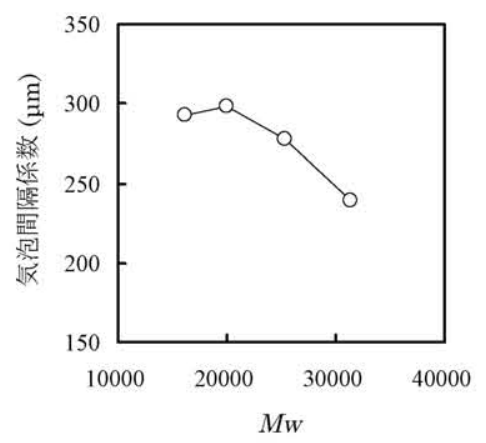

Fig. 6. 練り上がり直後のコンクリートの気 泡間隔係数と用いたPC-25のMWとの関係 コンクリート調合: Table 3, MIX 3; 骨材の 品質: Table 4, No. (4); 添加量: $0.17 \%$.

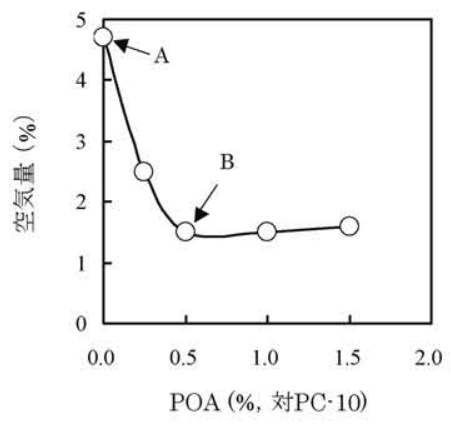

Fig. 7. 消泡剤の添加量と空気量との関係

PC-10: $0.24 \%$ (対セメント);

消泡剤: ポリオキシアルキレンアルキルエーテル (POA):

コンクリート调合: Table 3, MIX 1;

骨材の品犋: Table 4, No. (1)

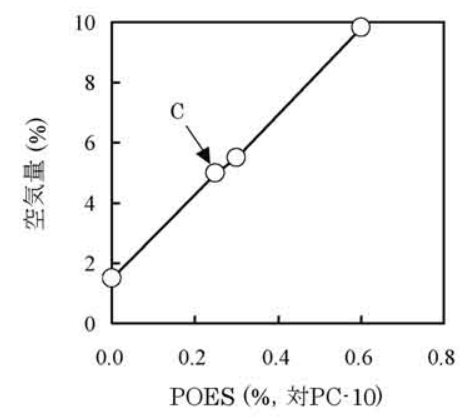

Fig. 9. AE剤の添加量と空気量との関係

PC-10: $0.24 \%$ (対セメント); POA: 0.5\% (対 PC-10); $\mathrm{AE}$ 剂: ポリオキシェチレンアルキル エーテル硫酸ナトリウム (POES); コンクリート调合: Table 3, MIX 1: 骨材の品質: Table 4, No. (1)

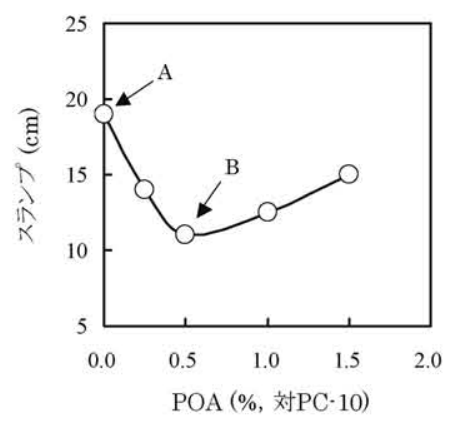

Fig. 8. 消泡剤の添加量とスランプとの関 係

PC·10: $0.24 \%$ (対セメント);

消泡剂: ポリオキシアルキレンアルキルエーテル

(POA);

コンクリート盷合: Table 3, MIX 1;

骨材の品質: Table 4, No. (1).

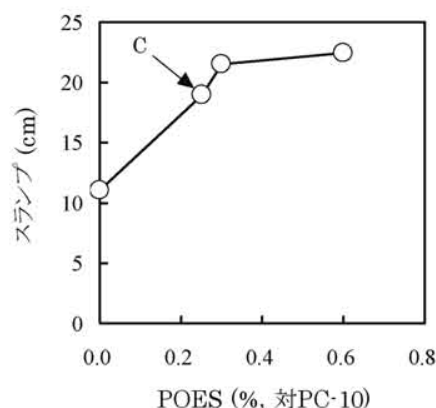

Fig. 10. AE剤の添加量とスランプとの関 係

PC-10: $0.24 \%$ (対セメント); POA: $0.5 \%$ (対 $\mathrm{PC} \cdot 10) ; \mathrm{AE}$ 剂: ポリオキシエチレンアルキル エーテル硫酸ナトリウム (POES); コンクリート䦙合: Table 3 , MIX 1 : 骨材の品質: Table 4, No. (1).
万かそれ以下で最大になった (Fig. 3)。一方で, $M w$ が 16200, 20000 と低い PC-25 では 1 2mm の粗い気泡が多く（Fig. 5), 気泡間隔係 数が大きくなった（Fig. 6)。村田らによると, コンクリート中の水 分の凍結による膨張圧を緩和し, 耐凍害性を確保するためには, 気

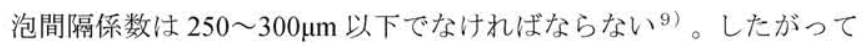
PC-25 の Mw は, Fig. 6 から約 3 万かそれ以上に設定する必要がある。

以上のことから, PC-25 には最適の減水性能と而凍害性を同時に 満足する $M w$ がないことがわかった。そこで次に, PC に消泡剤と $\mathrm{AE}$ 剂を加えて気泡分布を制御することを試みた。

\section{2 消泡剂, $\mathrm{AE}$ 剂による PC の空気量調整}

PCにはPC-10を用い, 消泡剤にPOA, AE剤にPOESを用いた。消泡

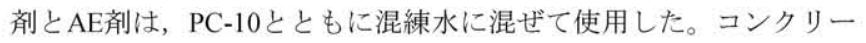

Table 6. POESとPOAの添加量の決定

\begin{tabular}{|c|c|c|c|c|c|c|c|}
\hline \multirow[b]{2}{*}{ No. } & \multicolumn{3}{|c|}{ 添加剂 } & \multicolumn{3}{|c|}{ 練り上がり直後 } & \multirow[b]{2}{*}{$\mid$\begin{tabular}{||} 
コンクリートの \\
種別
\end{tabular}} \\
\hline & $\begin{array}{c}\mathrm{PC}-10^{\mathrm{a})} \\
(\%) \\
\end{array}$ & $\begin{array}{c}\mathrm{POA}^{\mathrm{b})} \\
(\%)\end{array}$ & $\begin{array}{c}\text { POES }{ }^{\mathrm{b})} \\
(\%)\end{array}$ & $\begin{array}{c}\text { スランプ } \\
(\mathrm{cm})\end{array}$ & $\begin{array}{l}\text { スランプ } \\
\text { フロー } \\
(\mathrm{mm})\end{array}$ & $\begin{array}{c}\text { 空気量 } \\
(\%)\end{array}$ & \\
\hline 1 & 0.24 & 0 & 0 & 19.0 & 330 & 4.7 & コンクリートA \\
\hline 2 & 0.24 & 0.25 & 0 & 14.0 & 250 & 2.5 & \\
\hline 3 & 0.24 & 0.5 & 0 & 11.0 & 250 & 1.5 & コンクリート B \\
\hline 4 & 0.24 & 1.0 & 0 & 12.5 & 240 & 1.5 & \\
\hline 5 & 0.24 & 1.5 & 0 & 15.0 & 260 & 1.6 & \\
\hline 6 & 0.24 & 0.5 & 0.25 & 19.0 & 335 & 5.0 & コンクリートC \\
\hline 7 & 0.24 & 0.5 & 0.3 & 21.5 & 370 & 5.5 & \\
\hline 8 & 0.24 & 0.5 & 0.6 & 22.5 & 400 & 9.8 & \\
\hline 9 & 0.24 & 1.0 & 0.5 & 19.0 & 330 & 5.0 & |コンクリートD \\
\hline
\end{tabular}

a) セメント質量に対する質量 $\%,{ }^{\text {b) }} \mathrm{PC} \cdot 10$ 質量に対する質量 $\%$,

コンクリート調合: Table 3, MIX 1; 骨材の品質: Table 4, No. (1).
ト試験の結果をTable 6に示寸。

Fig. 7, Fig. 8は, PC-10の添加量を一定 (0.24\% ; 対セメント) に してPOAを添加したときの空気量とスランプを示す。点Aは, PC-10 のみを添加したコンクリートA (Table 6, No. 1) であり, 空気量は4.7\%, スランプは19cmであった。Fig. 7からわかるように, 空気量はPOAを 添加するにしたがって低下し, POAを0.5\%添加した点B (コンクリー トB : Table 6, No. 3) とそれ以上の添加で空気量は約 $1.5 \%$ まで下がり 最小になった。スランプも消泡剤を添加するにつれて低下し, 点 $\mathrm{B}$ で極小になり，それ以降はゆるやかに増加した（Fig. 8）。

次に, PC-10の添加量を $0.24 \%$ (対セメント), POAの添加量を $0.5 \%$ （対PC-10）に固定し，そこにPOESを添加して空気量とスランプを 測定した（Fig. 9, Fig. 10）。空気量もスランプも, POESを添加する と増大した。点C (コンクリートC: Table 6, No. 6) では, POESを $0.25 \%$ 添加（対PC-10）して空気量 $5.0 \%$, スランプ19cmのコンクリートが 得られた。すなわちコンクリートAとほぼ同じ空気量とスランプに復 帰させることができた。

\section{3 消泡剂, AE剂でPCの空気量を調整したコンクリートの物性}

コンクリートCでは, POAとPOESの使用量（コスト）を最小限に 抑えてコンクリートAと同じ空気量に復帰することができた。そこで, コンクリートAとコンクリートCで, 凍結融解抵抗性, 圧縮強度, 凝 結時間を比較した。また, 気泡組織をコンクリートAとコンクリート C，ならびにコンクリートDで比較した。 


\section{（1）凍結融解抵抗性}

Fig. 11に, コンクリーAとコンクリートCの相対動弾性係数 vs. サ イクル数を示す。ここでは，コンクリートA，コンクリートCでそれ ぞれふたつずつの供試体（コンクリートA:コンクリートA-1，コンク リートA-2；コンクリートC:コンクリートC-1，コンクリートC-2）を 測定した。平均值でコンクリートA，コンクリートCの相対動弾性係 数を比較したところ，300サイクルでコンクリートAが $96 \%$ ，コンク リートCが $98 \%$ であり, JIS A 6204:2006 コンクリート用化学混和剤に 示す高性能AE減水剂の凍結融解に対する抵抗性の值（相対動弹性係 数 $60 \%$ 以上) を満足した。さらに，600サイクルではコンクリートA が90\%，コンクリートCが $93 \% ， 900$ サイクルはコンクリートAが $81 \%$, コンクリートCが $96 \% ， 1200$ サイクルではコンクリートAが $54 \%$ ，コ ンクリートCが $95 \%$ あっあた。このようにコンクリートCの相対動弾 性係数は，1200サイクルまでほとんど低下が見られず, 非常に良好 な值を維持した。結果として，コンクリートAはおよそ500サイクル から相対動弹性係数の低下が始まるのに対し, コンクリートCはそれ よりもかなり遅くおよそ1200サイクルから低下が始まった。

また, 重量損失は, コンクリートA, コンクリートCともに1300サ イクルあたりから始まり（Fig. 12），両コンクリートとも重量損失 がほとんど見られない段階で相対動弾性係数の低下が見られた。

\section{（2）気泡間隔係数}

相対動弾性係数に違いが見られたコンクリートAとコンクリート C，およびコンクリート D（す心゙て材令 3 日の硬化コンクリート） の気泡間隔倸数を,リニアトラバース法で比較した。結果を Table 7 に示す。 300 サイクルでの相対動弾性係数はコンクリート A，コン クリートCともに $90 \%$ 以上あり良好であったにもかかわらず, 気泡 間隔係数はコンクリート A が $329 \mu \mathrm{m}$, コンクリート C は $349 \mu \mathrm{m}$ で, 耐凍害性に必要な $250 \sim 300 \mu \mathrm{m}^{9)}$ よりも大きな值であった。そ して，コンクリート C は 1200 サイクルで $90 \%$ 以上と特別に良好な 相対動弾性係数を示したが，気泡間隔係数は，コンクリート A より もやや大きい值であった。また, コンクリート Dの気泡間隔係数も $345 \mu \mathrm{m}$ と大きかった。

次に, これらの硬化コンクリートで気泡間隔係数 vs. 気泡径およ び空気量 vs. 気泡径の関係を比較した（Table 8, Fig. 13）。気泡間 隔係数の計算は次式(2) ${ }^{10}$ ) を用いた。

$$
L=(3 / \alpha)\left\{1.4 \times(p / A+1)^{1 / 3}-1\right\}
$$

(ここで, $L$ : 気泡間隔係数 $(\mathrm{cm}), \alpha$ : 気泡の比表面積 $\left(\mathrm{cm}^{2} / \mathrm{cm}^{3}\right)$,

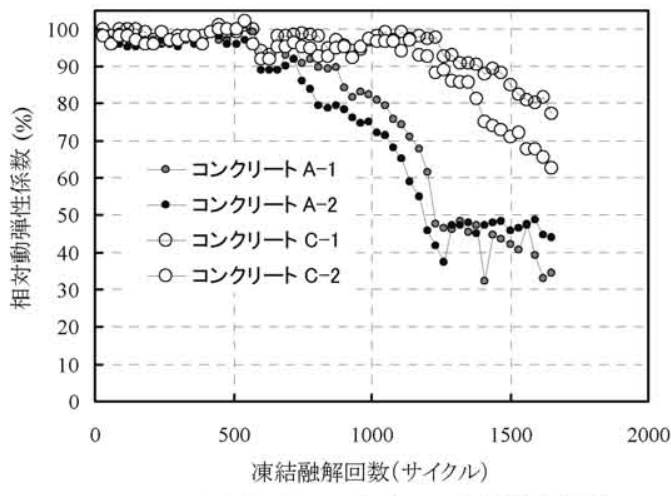

Fig. 11.コンクリート Aとコンクリート Cの凍結融解抵抗性 コンクリート A: PC·10，0.24\% (対セメント): コンクリート C : PC-10, $0.24 \%$ (対セメント), POA， 0.5\% (対 PC-10), POES, $0.25 \%$ (対 PC-10);

コンクリート調合: Table 3, MIX 1: 骨材の品澌: Table 4, No. (1).

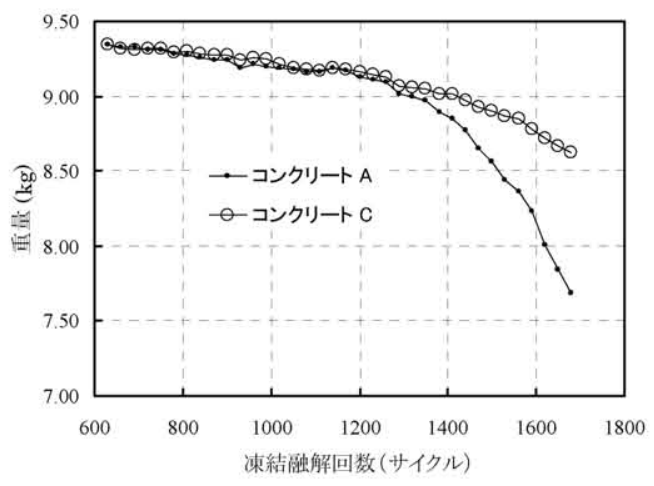

Fig. 12. 重量変化

$p:$ コンクリート中に占めるセメントペーストの体積比（空気量は含 まない) $\left(\mathrm{m}^{3} / \mathrm{m}^{3}\right), A$ : コンクリート中に占める空気泡の体積比 $\left(\mathrm{m}^{3} / \mathrm{m}^{3}\right), \mathrm{A} \times 100=$ 空気量（\%）を表す）

気泡径が大きくなるにしたがって気泡間隔係数も大きくなり，コ ンクリート A，コンクリート C, コンクリート D で大きな違いは無 かった（Table 8)。

空気量については, Table 7 によと, コンクリート A は硬化前 後で 4.7\%から $3.5 \%$ まで大きく低下したのに対し, コンクリート C とコンクリート D では 5.0\%から 4.5\%へわずかに低下しただけで, 練り上がり直後の空気量をほぼ維持していた。また, Fig. 13 で 1000 $\mu \mathrm{m}$ 以下のエントレインドエアー量を比較すると, コンクリート $\mathrm{A}$, コンクリート $\mathrm{C}$, コンクリート D の順に増加していた。

\begin{tabular}{|c|c|c|c|c|c|c|c|c|c|c|}
\hline \multirow{3}{*}{ No. } & \multirow{3}{*}{$\begin{array}{l}\text { コンクリートの } \\
\text { 種別 }\end{array}$} & \multicolumn{3}{|c|}{ 添加剂 } & \multicolumn{3}{|c|}{ フレッシュコンクリート } & \multirow{2}{*}{\multicolumn{3}{|c|}{$\begin{array}{c}\text { 凍結融解試験 (Fig. 11)に用いた硬化コンク } \\
\text { リート（材令3日） }\end{array}$}} \\
\hline & & \multirow[b]{2}{*}{$\begin{array}{c}\mathrm{PC}-10^{\mathrm{a})} \\
(\%)\end{array}$} & \multirow[b]{2}{*}{$\begin{array}{c}\mathrm{POA}^{\mathrm{b})} \\
(\%) \\
\end{array}$} & \multirow[b]{2}{*}{$\begin{array}{c}\text { POES }{ }^{b)} \\
(\%)\end{array}$} & \multirow[b]{2}{*}{$\begin{array}{l}\text { スランプ } \\
(\mathrm{cm})\end{array}$} & \multirow{2}{*}{$\begin{array}{l}\text { スランプ } \\
\text { フロー } \\
(\mathrm{mm})\end{array}$} & \multirow[b]{2}{*}{$\begin{array}{c}\text { 空気量 } \\
(\%)\end{array}$} & & & \\
\hline & & & & & & & & $\begin{array}{c}\text { 気泡間隔係数 } \\
(\mu \mathrm{m}) \\
\end{array}$ & $\begin{array}{c}\text { 比表面積 } \\
\left(\mathrm{mm}^{2} / \mathrm{mm}^{3}\right)\end{array}$ & $\begin{array}{c}\text { 空気量 } \\
(\%)\end{array}$ \\
\hline 1 & コンクリートA & 0.24 & 0 & 0 & 19.0 & 330 & 4.7 & 329 & 17.3 & 3.5 \\
\hline 2 & コンクリートC & 0.24 & 0.5 & 0.25 & 19.0 & 335 & 5.0 & 349 & 14.6 & 4.5 \\
\hline 3 & コンクリートD & 0.24 & 1.0 & 0.5 & 19.0 & 330 & 5.0 & 345 & 14.7 & 4.5 \\
\hline
\end{tabular}

Table 8，硬化コンクリート (Table 7)の気泡径と気泡間隔係数との関係

\begin{tabular}{|c|c|c|c|c|c|c|c|}
\hline 気泡径 $(\mu \mathrm{m})$ & $10 \sim 100$ & $100 \sim 150$ & $150 \sim 300$ & $300 \sim 500$ & $500 \sim 1000$ & $1000 \sim 2000$ & $2000 \sim 3000$ \\
\hline コンクリトA & 296 & 582 & 870 & 1384 & 2676 & 6154 & $\cdot$ \\
\hline コンクリートC & 340 & 552 & 710 & 1444 & 2348 & 5149 & 11765 \\
\hline コンクリートD & 343 & 579 & 659 & 1390 & 1993 & 5477 & 15429 \\
\hline
\end{tabular}


鎌田は，優れた耐凍害性を持つコンクリートの事例として, $\mathrm{AE}$ 剤や $\mathrm{AE}$ 減水剤が開発される以前の大正時代に小樽や函館でつくら れたコンクリートを紹介している ${ }^{11)}$ 。そして, 空気量, 水セメン ト比, スランプの中で耐凍害性にもっとも効果があるのは空気量で, エントラップトエアも少なからず効果をもつこと ${ }^{12)}$, 高流動コン クリートでは耐凍害性の確保に必要な気泡間隔係数は通常の $250 \mu$ $\mathrm{m}$ よりやや大きめであること ${ }^{13)}$, 高強度コンクリートでは, 実験 を行った水セメント比 $28 \%$ から $55 \%$ のすべてで適切な空気量の導入 が必要なこと, 気泡間隔係数が $250 \mu \mathrm{m}$ を超えても高い耐久性指数 を示すものがあること, そして, 水セメント比の効果が空気量の効 果に匹敵するものとなり, 特に水セメント比が $37 \%$ から $32 \%$ にが ると耐久性指数は約 30 から約 65 に飛躍的に向上すること ${ }^{14)}$ を示 している。

また，村田らも空気量がコンクリートの凍結融解に対する抵抗性 を著しく増大するとしている。その理由として，コンクリート中の 粗大な孔隙内の水が凍結し, 体積を増し, 小さい孔隙に向かって水 が移動する際, この移動水が, 気泡内に流入して水圧を減じるとと もに水圧も吸収して膨張圧力を減じるためであると述べている ${ }^{9)}$ 。

これらの文献情報からは, コンクリート C が凍結融解試験で 1200 サイクルまでほとんど劣化が見られなかった理由は, 硬化後も練り 上がり直後の空気量をほぼ維持できていた為であろうと考えられた。

\section{(3) 表面張力}

一般に, 気泡内外の気圧差が外圧の $10 \%$ 以上になると気泡は消失 し, より大きな気泡一吸収される ${ }^{15)}$ 。気泡の内外気圧差 $\Delta \mathrm{P}$ は次 式(3)により求められる ${ }^{16}$ 。式(3)によると, 気泡が大きくなるほど, また, 表面張力が低いほど $\Delta \mathrm{P}$ が小さくなるので気泡は安定になる。

$$
\triangle \mathrm{P}=\left(\mathrm{P}-\mathrm{P}_{0}\right)=4 \gamma /(101.33 \times \mathrm{R})
$$

(ここで, $\mathrm{P}$ : 気泡の内圧 $; \mathrm{P}_{0}$ : 外界の圧 $(1 \mathrm{~atm}) ; \gamma$ : 表面張力 $(\mathrm{mN} / \mathrm{m}) ; \mathrm{R}$ : 気泡の直径 $(\mu \mathrm{m})$ を表す $)$

そこで, コンクリート A とコンクリート C のセメントろ液の表面 張力を以下のようにして推定した。

まず，コンクリート A およびコンクリート C と同じ水セメント 比 (47\%) のセメントペーストをろ過してセメントろ液を調製した。 また, PC の吸着率は水セメント比が $60 \%$ から $1000 \%$ と大きく変わ っても大きな影響を受けないので17), 凍結融解試験（Fig. 11）に 用いたコンクリート AおよびコンクリートCの PC-10 吸着率は, Fig. $14^{177)}$ の結果に基づいて $52 \%$ とた。なお，このときの吸着量はセ メント質量に詨して $1.2 \mathrm{mg} / \mathrm{g}$ であり, 飽和吸着量（約 $1.5 \mathrm{mg} / \mathrm{g}$ ） 17) には至っていない。したがって, コンクリートに添加した PC-10の $48 \%$ がセメントに吸着せずにセメントペースト中の溶液（セメント ろ液）にとどまっていたことになる。そこで，セメントろ液中の PC-10 溶液の濃度は $2450 \mathrm{ppm}$ となり, この溶液を調製して, コンク リート A のセメントろ液相当品と呼ぶことにする。また, 同様にコ ンクリート C でセメントに吸着せずセメントろ液中に存在する PC-10, POES, POAの濃度はそれぞれ 2450ppm, $12.8 \mathrm{ppm}, 25.5 \mathrm{ppm}$ となり, この溶液も調製してコンクリートCのセメントろ液相当品 とした。さらに, セメントろ液を水に代えて上と同じ濃度の PC-10, および $\mathrm{PC}-10$ と消泡剈, $\mathrm{AE}$ 凰を加えた水溶液 $\mathrm{A}$, 水溶液 $\mathrm{C}$ を調製

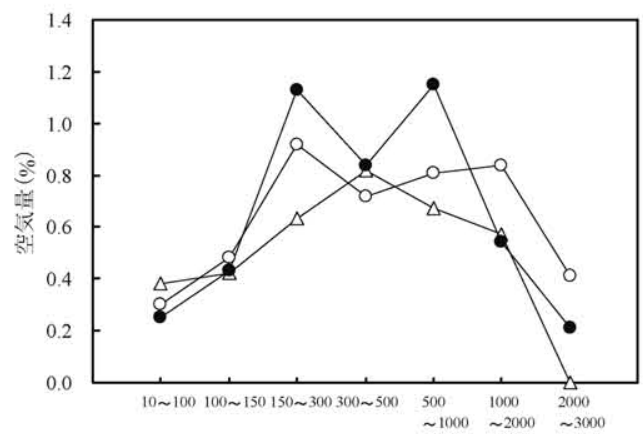

気泡径 $(\mu \mathrm{m})$

Fig. 13、硬化コンクリート(Table 7)の気泡分有 $\triangle \mathrm{:} \mathrm{コンクリート} \mathrm{A；} \mathrm{O} \mathrm{:} \mathrm{コンクリート} \mathrm{C;} \mathrm{:} \mathrm{:コンクリート} \mathrm{D}$ コンクリート调合: Table 3, MIX 1; 骨材の品質: Table 4, No. (1).

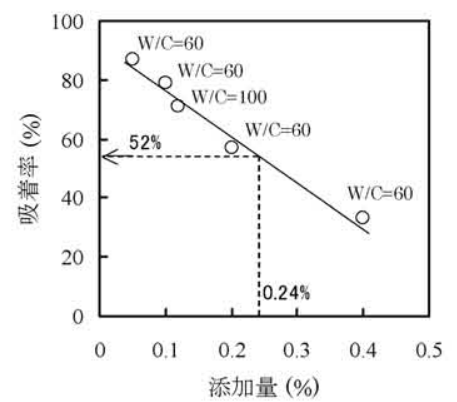

Fig. 14. PC-10の添加量と吸着率との関 係 ${ }^{17)}$

Table 9. 表面張力
\begin{tabular}{|c|c|c|}
\hline No. & 水溶液 & $\begin{array}{c}\text { 表面張力 } \\
(\mathrm{mN} / \mathrm{m})\end{array}$ \\
\hline 1 & コンクリート Aのセメントろ液相当品 & 62.4 \\
\hline 2 & コンクリートCのセメントろ液相当品 & 60.2 \\
\hline 3 & 水溶液 $\mathrm{A}$ & 71.3 \\
\hline 4 & 水溶液 $\mathrm{C}$ & 69.7 \\
\hline
\end{tabular}

Table 10. 気泡の内圧 $\left(\mathrm{P}-\mathrm{P}_{0}: \mathrm{atm}\right)$ と気泡 径, 表面張力との関係

\begin{tabular}{|r|r|r|}
\hline \multirow{2}{*}{$\begin{array}{c}\text { 気泡径 } \\
(\mu \mathrm{m})\end{array}$} & \multicolumn{2}{|c|}{ 表面張力 $(\mathrm{mN} / \mathrm{m})$} \\
\cline { 2 - 3 } & 62.4 & 60.2 \\
\hline 0.001 & 2463 & 2376 \\
\hline 0.01 & 246 & 238 \\
\hline 0.1 & 25 & 24 \\
\hline 1 & 2.463 & 2.376 \\
\hline 2 & 1.232 & 1.188 \\
\hline 5 & 0.493 & 0.475 \\
\hline 10 & 0.246 & 0.238 \\
\hline 20 & 0.123 & 0.119 \\
\hline 25 & 0.099 & 0.095 \\
\hline 50 & 0.0493 & 0.0475 \\
\hline 100 & 0.0246 & 0.0238 \\
\hline 150 & 0.0164 & 0.0158 \\
\hline 200 & 0.0123 & 0.0119 \\
\hline 300 & 0.0082 & 0.0079 \\
\hline 500 & 0.0049 & 0.0048 \\
\hline 1000 & 0.0025 & 0.0024 \\
\hline 2000 & 0.0012 & 0.0012 \\
\hline & & \\
\hline
\end{tabular}

し, それらの表面張力も測定した。結果を Table 9 に示す。セメン トろ液相当品では, コンクリート Cの方が表面張力は $2.2 \mathrm{mN} / \mathrm{m}$ 低く, 水溶液でも $\mathrm{C}$ の方が $1.6 \mathrm{mN} / \mathrm{m}$ 低いことがわかった。したがって, コ ンクリート Cの方がコンクリート Aよりも気泡を安定に維持する効 果があることが確認された。しかし，それらの表面張力の值から気 
泡の内圧を比較すると，わずかな違いである（Table 10）。また， $20 \mu \mathrm{m}$ 以下の気泡は気泡内外の圧力差が外圧の $10 \%$ 以上 $\left(\mathrm{P}-\mathrm{P}_{0}>\right.$ 0.1）あるので溶解していると考えられる ${ }^{15)}$ ，16)。

Fig. 15 に, PC-10, POES, POA 水溶液の表面張力を示寸。矢印 で測定值を示したプロットは，コンクリートCのセメントろ液中の PC-10, POES, POA（それぞれ 2450ppm, 12.8ppm, 25.5ppm) に相 当する。これらのプロットを見ると, POES は表面張力を水よりも $1.0 \mathrm{mN} / \mathrm{m}$ 下げ， PC-10（水溶液 $\mathrm{A}$ にも相当）は $1.2 \mathrm{mN} / \mathrm{m}$ 下げる。一 方, $\mathrm{POA}$ (水への溶解度が低く水中では白濁する）は水と同等の表 面張力であった。したがって, 水溶液 C の表面張力が水溶液 $\mathrm{A}$ より $1.6 \mathrm{mN} / \mathrm{m}$ も低くなるには他の要因があることが推察された。

Fig. 16 に示寸ように, POA の動的表面張力は, POES や PC-10 と は違ってわずかな気泡発生数で水の表面張力以上に復帰している。 このように気泡を発生させると表面張力が水に戻る理由は, 空気と 水の界面に集まっていた界面活性剂が，発生した気泡で乱されて水 中に拡散し, 空気と水とがほとんど直接に接触するようになるため である。したがって, 最も早く表面張力が上がった POAの界面活性 がもっとも低いと言える。一方, 気泡発生数が最も低い時（約 0.05 個/秒) の表面張力はPOA が約 $71 \mathrm{mN} / \mathrm{m}$, POES, PC- 10 が約 $70 \mathrm{mN} / \mathrm{m}$ と低い。これは, 水の表面にこれらの界面活性剤が集まって空気と 水が直接接触する面積を減少させているためである ${ }^{18)}$ 。

我々は以前, PGM-10（Mw472, 分子の長さ $2.8 \mathrm{~nm})$ が, $\mathrm{NaCl}$ 水 溶液中で疎水会合して分子量が見かけ増大寸ること（光散乱による 測定で $M w 2760$, 慣性半径 ( $\left.\langle S\rangle^{1 / 2}\right) 52.1 \mathrm{~nm}$ と増大寸る) を報告した 5)。また, POAの類似化合物であるポリ $(n=9)$ オキシェチレンア ルキルエーテル（Mw596, アルキル基は炭素数 12〜14 の混合物）も 同様にして $\mathrm{NaCl}$ 水溶液中での光散乱を測定したところ, 分子量が 596 から $26300\left(\langle S\rangle^{1 / 2} 34.3 \mathrm{~nm}\right)$ ととても大きくなることがわかって いる。そこで, POES と POA を混合して表面張力を測定してみた。 全体の濃度を100ppm とし, POES/POAをそれぞれ $16.7 \mathrm{ppm} / 83.3 \mathrm{ppm}$, $33.3 \mathrm{ppm} / 66.7 \mathrm{ppm}, 50 \mathrm{ppm} / 50 \mathrm{ppm}, 66.7 \mathrm{ppm} / 33.3 \mathrm{ppm}, 100 \mathrm{ppm} / 0 \mathrm{ppm}$ の濃度になるようにして混合した。結果を Fig. 17 に示す。横軸は POES の濃度でプロットした。その結果, POES のみの溶液 $(O)$ よ りも POES と POA を混合した溶液 (*) の方が表面張力を下げるこ とがわかった。この理由として, アルキル基どうしが相互作用して 見かけ上，新たな親水基一疎水基のバランスを生んだため表面張力 が下がったのであろうと考えられた。また, Fig. 13 でコンクリート D が多くのエントレインドエアーを導入した理由も, POA と POES の使用量がコンクリートCよりも多いので表面張力がさらに下がり, 気泡が安定化したためであろうと考えられた。相互作用の確認のた めに, Fig. 18 に, POES の 50ppm 水溶液と POES, POA をそれぞれ $50 \mathrm{ppm}$ 溶解させた水溶液の動的表面張力 $v s$. 気泡発生数を示す。そ れによると, POAの $50 \mathrm{ppm}$ 懸濁液の表面張力は水と同じ $72.5 \mathrm{mN} / \mathrm{m}$ であったにもかかわらず (Fig. 15), POAにPOES を加えた溶液 (*) の方が POES だけの溶液（O）よりも表面張力を低く維持できてい ることがわかる。

\section{（4）気泡分布}

次に, コンクリートAとコンクリート C のフレッシュコンクリー トで，気泡分布の経時変化を調べた。まず，新たに作製したコンク リートの添加剤組成とスランプ, 空気量, 及び硬化後のコンクリー
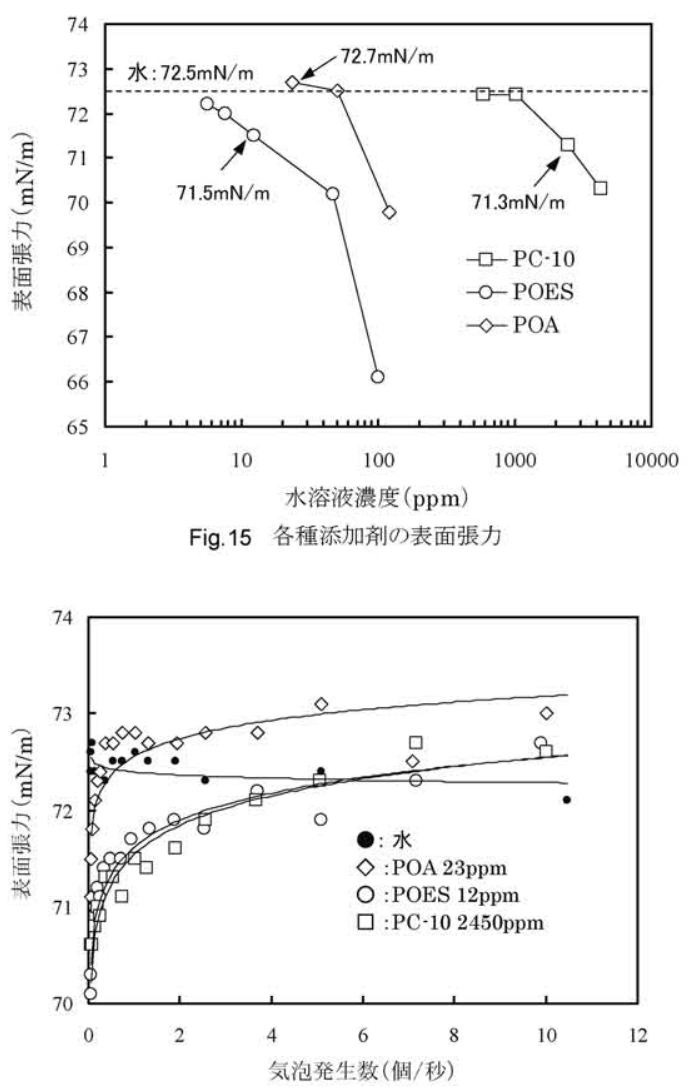

Fig. 16 表面張力 vs. 気泡発生数

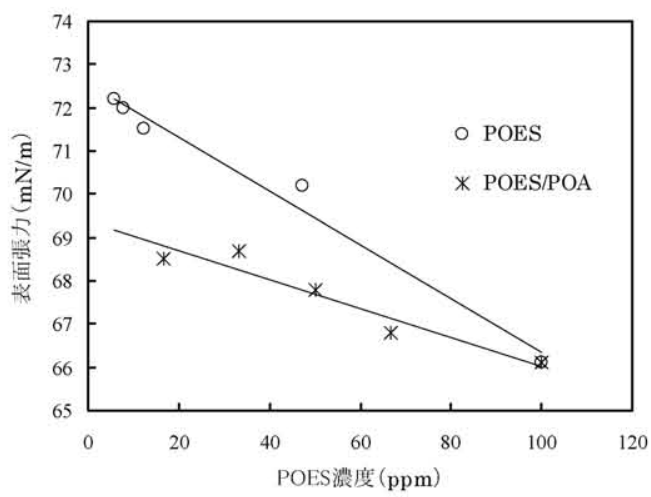

Fig. 17 POAの効果

POES/POAは16.7/83.3, 33.3/66.7, 50/50, 66.7/33.3, 100/0 (単位 はppm)の剩合で混合し, POESの灌度でブロットした。

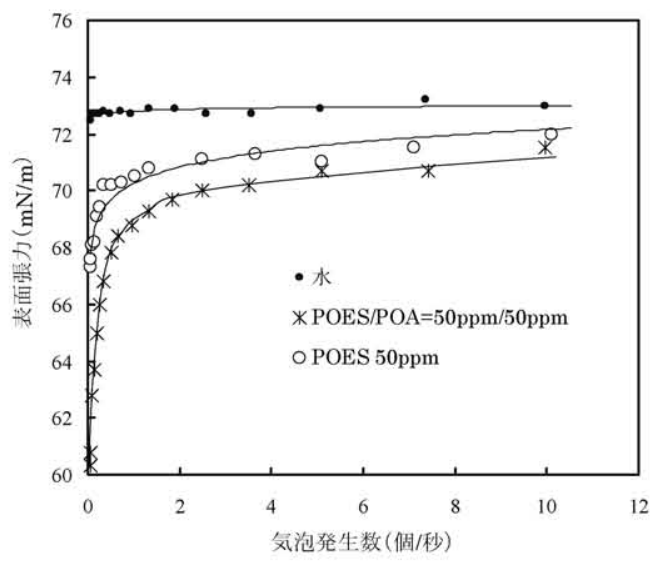

Fig. 18 表面張力 $v s$. 気泡発生数 
Table 11.フレッシュコンクリートと硬化コンクリートの性状

\begin{tabular}{|c|c|c|c|c|c|c|c|c|c|c|}
\hline \multirow[b]{2}{*}{ No. } & \multirow[b]{2}{*}{$\begin{array}{c}\text { コンクリートの } \\
\text { 種別 }\end{array}$} & \multicolumn{3}{|c|}{ 添加剤 } & \multicolumn{3}{|c|}{ フレッシュコンクリート } & \multicolumn{3}{|c|}{ 硬化コンクリート } \\
\hline & & $\begin{array}{c}\mathrm{PC}-10^{a)} \\
(\%)\end{array}$ & $\begin{array}{c}\mathrm{POA}^{\mathrm{b})} \\
(\%)\end{array}$ & $\begin{array}{c}\text { POES }{ }^{\mathrm{b}} \\
(\%)\end{array}$ & $\begin{array}{c}\text { スランプ } \\
(\mathrm{cm})\end{array}$ & $\begin{array}{l}\text { スランブ } \\
\text { フロー } \\
(\mathrm{mm})\end{array}$ & $\begin{array}{c}\text { 空気量 } \\
\text { (\%) }\end{array}$ & 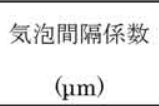 & $\begin{array}{c}\text { 比表面積 } \\
\left(\mathrm{mm}^{2} / \mathrm{mm}^{3}\right)\end{array}$ & $\begin{array}{c}\text { 空気量 } \\
(\%)\end{array}$ \\
\hline 1 & コンクリート A & 0.15 & 0 & 0 & 16.5 & 275 & 5.1 & 345 & 16.9 & 3.3 \\
\hline 2 & コンクリート C & 0.15 & 0.5 & 0.25 & 18.0 & 295 & 4.4 & 393 & 14.7 & 3.4 \\
\hline
\end{tabular}

Table 12. 硬化コンクリート(Table 11)の気泡径と気泡間隔係数との関係

\begin{tabular}{|c|c|c|c|c|c|c|c|}
\hline 気泡径 $(\mu \mathrm{m})$ & $10 \sim 100$ & $100 \sim 150$ & $150 \sim 300$ & $300 \sim 500$ & $500 \sim 1000$ & $1000 \sim 2000$ & $2000 \sim 3000$ \\
\hline コンクリートA & 337 & 578 & 752 & 1536 & 2929 & 7034 & 18277 \\
\hline コンクリートC & 408 & 617 & 803 & 1406 & 2550 & 6900 & 16489 \\
\hline
\end{tabular}

トの気泡パラメーターを Table 11 に示す。Table 11 から硬化前後の 空気量を比べると, Table 7 と同様にコンクリート A の方が空気量 の低下が大きかった。気泡間隔係数と気泡径との関係（Table 12） も Table 8 と同様で, A と C で大きな違いは無かった。気泡分布も, コンクリート C では 500〜 $3000 \mu \mathrm{m}$ の大きな気泡がやや増えており

(Fig. 19)，これも Fig. 13 と同じ傾向で，コンクリートCでは小さ い気泡から大きい気泡へと順次気泡が成長しているように見える。

Fig. 20, Fig. 21 では, それぞれコンクリートA, コンクリート C の練り上がり直後から 90 分後までのフレッシュコンクリートの空 気量（積算值）と気泡径との関係を示した。気泡の量を $500 \mu \mathrm{m}$ 以 下の微細な気泡で比較すると, 混練直後（○印）のそれはコンクリ ートAが $5.2 \%$, コンクリート C は $3.5 \%$ コンクリート A の方が多 いが， 90 分後 (৩) ではコンクリート A が 1.6\%, コンクリート C が $2.2 \%$ ま゙下がり, コンクリート A の方が空気量の低下が大きか った。なお AVA では直径が $3000 \mu \mathrm{m}$ 以上の気泡は測定できず6)， 今回の試験では $100 \mu \mathrm{m}$ 以下の気泡も測定されなかった。

Fig. 22〜25 では, コンクリート A, コンクリート Cの練り上がり 直後から 90 分後までの空気量の経時変化を, 気泡径 $100 \sim 150 \mu \mathrm{m}$, 150〜300 $\mu \mathrm{m}, 300 \sim 500 \mu \mathrm{m}, 500 \sim 2000 \mu \mathrm{m}$ に分けて比較した。150 $\mu \mathrm{m}$ 以上の気泡分布は, コンクリート $\mathrm{A}$, コンクリート $\mathrm{C}$ とも同様 で時間とともに低下した（Fig. 23〜25）。一方，100〜150 $\mu \mathrm{m}$ （Fig. 22）の空気量は，コンクリートA ではやはり時間とともに減少する のに対して, コンクリート C は増加した。すなわち, コンクリート $\mathrm{C}$ では $100 \mu \mathrm{m}$ 以下の気泡が，それよりも大きい $100 \sim 150 \mu \mathrm{m}$ の気 泡の中へ時間とともに吸収されているものと考えられる。

Fig. 26 は, 気泡径 $100 \sim 150 \mu \mathrm{m}$ の気泡間隔係数の経時変化を示 す。右端には, 硬化後の気泡間隔係数（Table 12 : コンクリートA, $578 \mu \mathrm{m}$; コンクリート C, $617 \mu \mathrm{m})$ を加えた。そして, Fig. 27 は,

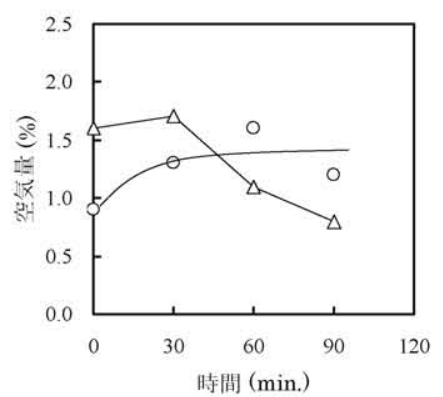

Fig. 22. フレッジュコンクリート(Table 11) 中の気泡径100-150umの空気量の経時変 化 $\triangle$ : コンクリート A; O : コンクリート C

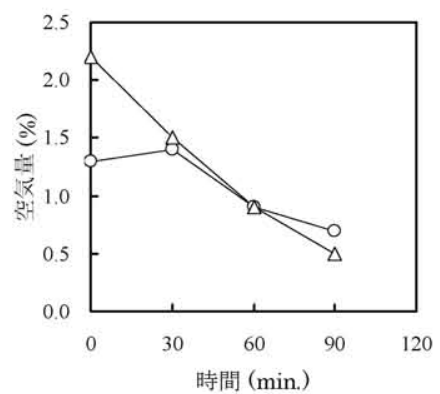

Fig. 23. フレッシュコンクリート(Table 11)

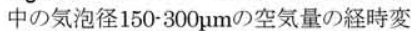
化 $\triangle$ : コンクリート $\mathrm{A} ; \mathrm{O}:$ コンクリート C.

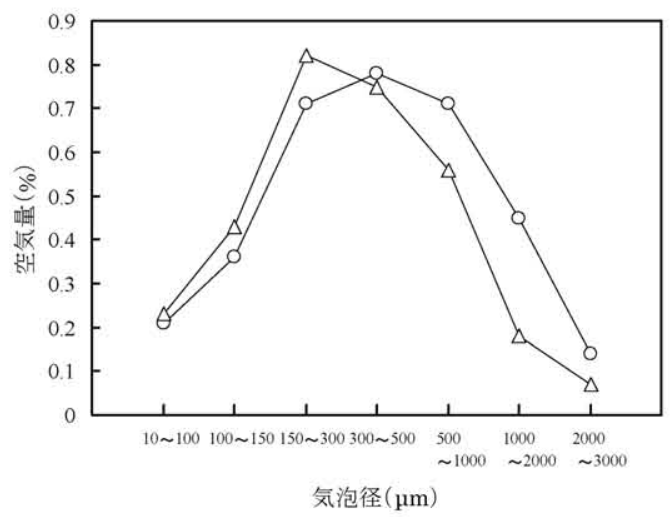

Fig. 19. 硬化コンクリート(Table 11)の気泡分布 $\triangle$ :コンクリートA， O:コンクリート C; コンクリート調合: Table 3 , MIX 2 ; 骨材の品犋: Table 4, No. (3).

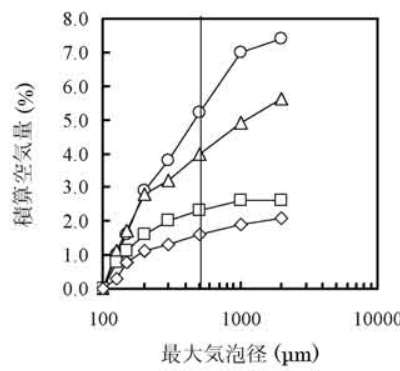

Fig. 20.フレッシュコンクリートA（Table 11)の空気量の経時変化

○: $0 \mathrm{~min}$. (練り上がり直後)

$\triangle: 30 \mathrm{~min} ., \square: 60 \mathrm{~min} ., \diamond: 90 \mathrm{~min}$

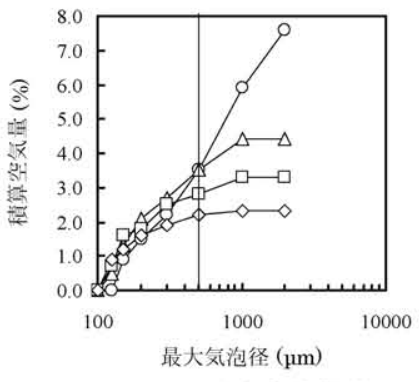

Fig. 21. フレッシュコンクリート C (Table 11)の空父量の経時変化

O: $0 \mathrm{~min}$. (練り上がり直後)

$\triangle: 30 \mathrm{~min} ., \square: 60 \mathrm{~min} ., \diamond: 90 \mathrm{~min}$.

100〜 $2000 \mu \mathrm{m}$ のすべての気泡から求めた気泡間隔係数の経時変化 である。右端には硬化コンクリートの気泡間隔係数（Table 11：コ ンクリート A, $345 \mu \mathrm{m}$ ；コンクリート C , $393 \mu \mathrm{m})$ を加えた。Fig.

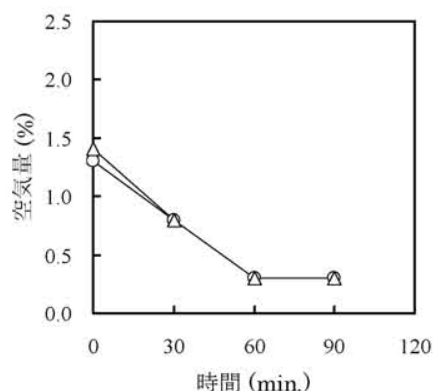

Fig. 24. フレッシュコンクリート(Table 11)

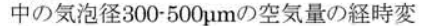
化 $\triangle$ : コンクリート $\mathrm{A} ; \mathrm{O}:$ コンクリート $\mathrm{C}$.

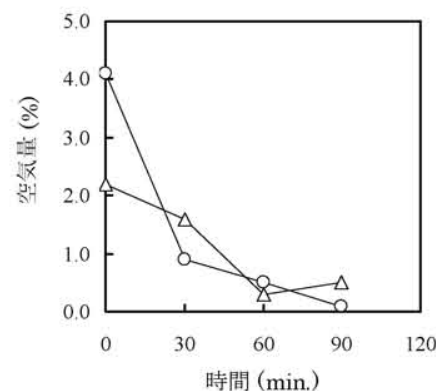

Fig. 25. フレッシュコンクリート(Table 11) 中の気泡径500-2000umの空気量の経時 変化

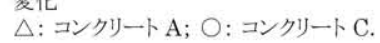


26, Fig. 27 とも気泡間隔係数は, コンクリートA では練り上がり直 後から増大寸るが, コンクリート C は練り上がりから 1 時間後まで は減少してその後増大寸る。これは, おそらく 100 $150 \mu \mathrm{m}$ の空気 量が時間とともに増加したためであり（Fig. 22）, 消泡鼡, AE 剤を 添加することで表面張力が下がり気泡が安定化した結果と考えられ る。そこで, 消泡剤, $\mathrm{AE}$ 㓱の種類と添加量を研究してセメントろ 液の表面張力をさらに下げることができれば，微細な気泡をさらに 安定させて気泡間隔係数を低く抑えることができる可能性がある。

\section{（5）圧縮強度と凝結時間}

Table 13 では, コンクリート A とコンクリート C の圧縮強度, 凝 結時間を示す。両コンクリートに明確な違いは無かった。

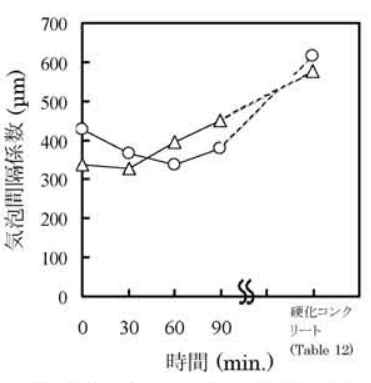

Fig. 26. フレッシュコンクリート(Table 11) 中の父泡径 100-150umの父泡間隔係数の 経時変化

$\mathrm{O}$ : Concrete $\mathrm{C} ; \triangle$ : Concrete A

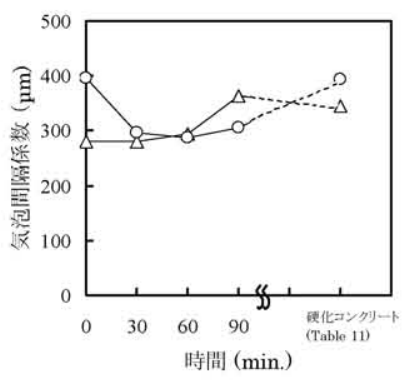

Fig. 27. フレッシュコンクリート(Table 11) の父泡問隔係数の経時変化

$\mathrm{O}$ : Concrete C; $\triangle$ : Concrete A.

Table 13. コンクリートAとコンクリート Cの性状

\begin{tabular}{|c|c|c|c|c|c|c|c|c|c|c|c|c|}
\hline \multirow{3}{*}{ No. } & \multirow{3}{*}{$\begin{array}{c}\text { コンクリートの } \\
\text { 種別 }\end{array}$} & \multicolumn{3}{|c|}{ 添加㓮 } & \multirow{3}{*}{$\begin{array}{l}\text { スランプ } \\
(\mathrm{cm}) \\
\end{array}$} & \multirow{3}{*}{$\begin{array}{l}\text { スランプ } \\
\text { フロー } \\
(\mathrm{mm})\end{array}$} & \multirow{3}{*}{$\begin{array}{c}\text { 空気量 } \\
(\%) \\
\end{array}$} & \multirow{2}{*}{\multicolumn{3}{|c|}{$\begin{array}{c}\text { 圧縮強度 } \\
(\mathrm{MPa}) \\
\end{array}$}} & \multirow{2}{*}{\multicolumn{2}{|c|}{$\begin{array}{c}\text { 凝結時間 } \\
\text { (hour-min.) }\end{array}$}} \\
\hline & & \multirow{2}{*}{$\begin{array}{c}\mathrm{PC} \cdot 10^{\mathrm{a})} \\
(\%)\end{array}$} & \multirow{2}{*}{$\begin{array}{c}\mathrm{POA}^{\mathrm{b})} \\
(\%)\end{array}$} & \multirow{2}{*}{$\begin{array}{c}\text { POES }{ }^{\mathrm{b})} \\
(\%)\end{array}$} & & & & & & & & \\
\hline & & & & & & & & 1日 & 7日 & 28 日 & 始発 & 終結 \\
\hline 1 & \multirow{2}{*}{ コンクリート A } & 0.11 & 0 & 0 & 19.0 & 325 & 5.2 & 8 & 30 & 37 & $5 \cdot 18$ & $7 \cdot 01$ \\
\hline 2 & & 0.11 & 0 & 0 & 19.0 & 325 & 5.3 & 8 & 29 & 38 & $5 \cdot 16$ & $7 \cdot 12$ \\
\hline 3 & \multirow{2}{*}{ コンクリート C } & 0.11 & 0.5 & 0.25 & 18.5 & 305 & 4.6 & 9 & 32 & 41 & $5 \cdot 03$ & $6 \cdot 33$ \\
\hline 4 & & 0.11 & 0.5 & 0.25 & 18.0 & 305 & 4.5 & 8 & 32 & 42 & $5 \cdot 16$ & $7 \cdot 20$ \\
\hline
\end{tabular}

a) セメント質量に対する質量 $\%,{ }^{\text {b) }}$ PC-10質量に対する質量\%, コンクリート調合: Table 3, MIX 1; 骨材の品質: Table 4, (2).

\section{5.まとめ}

$\mathrm{PC}$ の $\mathrm{AE}$ 性低減について, 以下のことが明らかとなった。

（1）セメント分散性能を発現するモノマー組成比の範囲で, 側鎖 の長さが 10 モルから 25 モル, 30 モル, 35 モルと長くなるにしたが って, $\mathrm{AE}$ 性は低隇する。

(2) PC-25 で $M w$ を約 1.5 万と低くすると少ない添加量で所望の スランプを得ることができるが，粗い気泡が多く気泡間隔係数は大 きくなる。また，気泡間隔係数を $250 \sim 300 \mu \mathrm{m}$ 以下にするには $M w$ は約 3 万かそれ以上にしなければならない。したがって, 最適の減 水性能と耐凍害性を同時に両立させる $M w$ は無かった。

(3) PC-10を添加したコンクリート A は 500 サイクルで $90 \%$ 以上 の凍結融解抵抗性を示した。PC-10に消泡剤, AE 凨を加えて同じ空 気量に戻したコンクリート C は 1200 サイクルまで $90 \%$ を維持した。

（4）コンクリート C は，コンクリート A 上りも硬化後も練り上が り直後の空気量をほぼ維持できていた。その結果, コンクリート C は高い凍結融解抵抗性を示したのであろうと考えられた。

（5）コンクリート C の気泡が安定な理由は, セメントろ液の表面 張力が低いためであろうと考えられた。

（6）コンクリートA とコンクリート C で圧縮強度と凝結時間は同 等であった。

\section{謝辞}

コンクリートの諸物性を測定するにあたり，株式会社日本触媒，機 能性化学品研究所第 1 研究グループの橋本真樹氏, 岩井正吾氏から ご協力とご助言をいただきました。各種 PC の合成では株式会社日 本触媒, 機能性化学品研究所第 1 研究グループの湯浅務氏, 大谷真 理氏にご協力をいただきました。ここに樑く感謝の意を表します。

\section{参考文献}

1) 大川裕: 高性能AE 減水剂ゆ特徵・種類およU牲能 コンクリート工学, Vol.37, No.6, pp. $15-20,1999.6$
2) 河井徹: 高性能 $\mathrm{AE}$ 減水剤を用いたコンクリートの適用の現状, コンク リート工学, Vol. 37, No. 6, pp. 21·26, 1999.6.

3) 守屋慶隆, 太田晃: 高性能 $\mathrm{AE}$ 減水剂の最近の動向, 材料, Vol. 43, No. 491, pp. 919.929, 1994. 8.

4) 枚田健, 名和豊春: ポリカルボン酸系高性能 $\mathrm{AE}$ 減水剤の空気連行性に ついて, 日本建築学会構造系論文集, Vol.74, No.636, pp.185·191, 2009.2 .

5）枚田 健，名和豊春，湯浅 務：ポリメタクリル酸・ポリエチレングリ コールグラフトコポリマーを主剤とするコンクリート用高性能 $\mathrm{AE}$ 減 水剂，高分子論文集, Vol. 65, No. 11, pp. 659-669, 2008.

6) Donald D. Magura: Evaluation of the Air Void Analyzer, Concrete International, Vol. 18, No. 8, pp. 55·59, 1996.

7）浜幸雄, 太田宏平：フレッシュコンクリートによる気泡組織の測定方法 に関する研究，コンクリート工学年次論文集，Vol. 26, No. 1, pp. 669-674, 2004.

8）北原文雄, 玉井康勝, 早野茂夫, 原一郎：界面活性剤 物性 - 応用 - 化学 生態学, 講談社サイエンティフィク, pp. 99-100, 1980.

9）村田二郎, 岩崎訓明, 児玉和巳：コンクリートの科学と技術, 山海堂, pp. $26 \cdot 29,1996$

10) T. C. Powers: Void Spacing as a Basis for Producing Air-Entrained Concrete, Journal of the American Concrete Institute, Vol. 50, pp. $741 \cdot 760,1954$

11）鎌田英治：寒椧地とコンクリート構造物の劣化，セメント・コンクリー 卜 化学とその応用, セメント協会, pp. 4·12, 1994.

12）藤井弘司，鎌田英治，洪悦郎：コンクリートの耐凍害性に及ぼす水セメ ント比, スランプ, 空気量の影響一既往の文献による凍結融解試験結果 の解析一, コンクリート工学年次論文集, Vol. 1, No.1, pp. 33·36, 1979.

13）權寧琟, 千歩修, 鎌田英治, 微粉末系の高流動コンクリートの気泡組織 と耐凍害性に関寸る研究，コンクリート工学年次論文集, Vol. 16, No.1, pp. $207 \cdot 212,1994$.

14）柏野謙二, 鎌田英治, 桂修：高強度コンクリートの耐凍害性に関する赛 験的研究, コンクリート工学年次論文集, Vol. 12, No.1, pp. 691·696, 1990.

15）羽原俊祐：コンクリートの構造とその物性「わかりやすいセメント科 学」, p. 83, セメント協会, 1993.

16）服部健一: 洗剤の泡とコンクリートの泡, コンクリート技術者のための セメント化学雑論, pp. 75·81, セメント協会, 1985.

17) 枚田 健, 名和豊春: ポリマー構造から吸着速度を制御したポリカルボ ン酸系減水剂の効果, 日本建築学会構造系論文集, Vol. 74, No. 639, pp. $765 \cdot 773,2009.5$.

18）藤本武彦：新·界面活性剂入門, pp 12-15, 三洋化成工業株式会社, 1976 . 